Anais da Academia Brasileira de Ciências (2006) 78(1): 123-131

(Annals of the Brazilian Academy of Sciences)

ISSN 0001-3765

www.scielo.br/aabc

\title{
Mutations in Collagen 18A1 (COL18A1) and their relevance to the human phenotype
}

\author{
MARIA RITA PASSOS-BUENO ${ }^{1}$, OSCAR T. SUZUKI ${ }^{1}$, LUCIA M. ARMELIN-CORREA ${ }^{1}$, \\ ANDRÉA L. SERTIÉ ${ }^{1}$, FLAVIA I.V. ERRERA ${ }^{1}$, KELLY BAGATINI ${ }^{1}$, \\ FERNANDO KOK $^{1,2}$ and KATIA R.M. LEITE ${ }^{3}$ \\ ${ }^{1}$ Centro de Estudos do Genoma Humano, Departamento de Genética e Biologia Evolutiva, \\ Instituto de Biociências, USP, Rua do Matão, 277, 05508-900 São Paulo, SP, Brasil \\ ${ }^{2}$ Serviço de Neurologia Infantil, Faculdade de Medicina, USP, \\ Av. Dr. Arnaldo, 455, 01246-903 São Paulo, SP, Brasil \\ ${ }^{3}$ Laboratório de Patologia Cirúrgica e Molecular, Hospital Sírio Libanês, \\ Rua Dona Adma Jafet, 91, 01308-050 São Paulo, SP, Brasil \\ Manuscript received on May 12, 2005; accepted for publication on May 16, 2005; \\ presented by LuCia MENDONÇA PREviato
}

\begin{abstract}
Collagen XVIII, a proteoglycan, is a component of basement membranes (BMs). There are three distinct isoforms that differ only by their $\mathrm{N}$-terminal, but with a specific pattern of tissue and developmental expression. Cleavage of its C-terminal produces endostatin, an inhibitor of angiogenesis. In its N-terminal, there is a frizzled motif which seems to be involved in Wnt signaling. Mutations in this gene cause Knobloch syndrome (KS), an autosomal recessive disorder characterized by vitreoretinal and macular degeneration and occipital encephalocele. This review discusses the effect of both rare and polymorphic alleles in the human phenotype, showing that deficiency of one of the collagen XVIII isoforms is sufficient to cause KS and that null alleles causing deficiency of all collagen XVIII isoforms are associated with a more severe ocular defect. This review besides illustrating the functional importance of collagen XVIII in eye development and its structure maintenance throughout life, it also shows its role in other tissues and organs, such as nervous system and kidney.
\end{abstract}

Key words: COL18A1, collagen XVIII, Knobloch syndrome, eye development, neuronal cell migration, craniosynostosis, polymorphisms, D1437N.

\section{INTRODUCTION}

Type XVIII collagen is a non-fibrillar proteoglycan collagen which, together with collagen $\mathrm{XV}$, form the subgroup of multiplexins (multiple triplehelix domains with interruptions) within the collagen family (Rehn and Pihlajaniemi 1994, Oh et al. 1994, Saarela et al. 1998). This protein forms

Correspondence to: Maria Rita Passos-Bueno

E-mail: passos@ib.usp.br; passosbuenom@terra.com.br homotrimers and contains an N-terminal noncollagenous domain (NC-11), 10 collagenous repeats alternated with 9 non-collagenous repeats and a C-terminal non-collagenous region, NC-1 (Saarela et al. 1998). The N-terminal region presents thrombospondin-1-like and frizzled motifs. This last motif is characterized by a conserved region of 120 amino acids containing a sequence of 10 invariantly spaced cysteines, the cysteine-rich domain or CRD (Xu and Nusse 1998). The frizzled 
domain binds Wnt signaling molecules, which are involved in cell proliferation, polarity and differentiation in various developmental processes (Wodarz and Nusse 1998). However, the function of the frizzled motif in collagen XVIII molecule is still not known (Lin et al. 2001, Elamaa et al. 2003). The Cterminal region $\mathrm{NC1}$, which contains a trimerization domain and the last 184 amino acid residues, can release endostatin $(20 \mathrm{kDa})$ and endostatin-like fragments by its cleavage with elastase and/or cathepsin L (Wen et al. 1999, Felbor et al. 2000, John et al. 2005). These fragments can be detected in blood plasma and tissue extracts (Sasaki et al. 1998), during physiological or pathological processing of collagen XVIII (Zorick et al. 2001, Strik et al. 2001, Dhar et al. 2002). Endostatin, first identified as a potent inhibitor of endothelial cell proliferation and migration, with the ability to reduce tumor growth, seems to play several other functions, including apoptosis induction (Dhanabal et al. 1999, Dixelius et al. 2000, Schmidt et al. 2004). Endostatin/collagen XVIII also acts in neuronal and renal epithelial cell migration (Ackley et al. 2001, Karihaloo et al. 2001, Lin et al. 2001) and interacts with at least two cell surface receptors (glypican and integrins), but its downstream targets are still unknown (Rehn et al. 2001, Karumanchi et al. 2001, Wickstrom et al. 2002, 2004, Abdollahi et al. 2004). Besides the C-terminal proteolytic fragments, there is also a soluble type XVIII collagen fragment derived from the NC11 domain, which contains the frizzled motif, with still unknown function (Elamaa et al. 2003). Most of the research on collagen XVIII was originally focused on endostatin because of its great potential to inhibit tumor angiogenesis. But it is also known that proteoglycans in the extracellular space play a major role in chemical signaling between cells as they can provide a reservoir for various secreted signaling molecules such as members of wingless/wnt, TGF-b and FGF families and cell adhesion molecules-like receptors (Lin et al. 2001, Aricescu et al. 2002). Therefore, collagen XVIII in the extracellular matrix may be important for defining plasticity of epithelial and endothelial cells in different organs and may be involved in determining cell polarity, influencing cell metabolism and differentiation (Lin et al. 2001).

Collagen XVIII is encoded by the COL18A1 gene, mapped to 21q22.3. This gene has 43 exons, which are transcribed in 3 distinct isoforms by use of two promoters and of an alternative splicing of the third exon. The three proteins differ only by their signal peptides and by part of the N-terminal region of the NC11 domain, and contain 303 (NC11303), 493 (NC11-493) and 728 (NC11-728) amino acid residues. NC11-303 mRNA is transcribed from the promoter located upstream of exon 1, and it does not contain exon 3. NC11-493 and NC11728 mRNAs are both transcribed by the promoter located in intron 2 and do not include exons 1 and 2. Isoform NC11-728 and NC11-493 are encoded by exon 3 and exons 4 through 43, but NC11-493 variant uses an internal splice donor site within exon 3, thus lacking 235 amino acid residues (Elamaa et al. 2003). The NC11-493 variant mRNA is mainly expressed in fetal and adult liver, whereas the NC11-303 variant was found at the highest levels in the fetal kidney (Saarela et al. 1998). NC11728 , is the only isoform containing the frizzled domain, it is also expressed in several tissues, with the highest levels in liver and lung (Elamaa et al. 2003). NC11-303 and NC11-728 are also expressed in human fetal brain and retina (Sertié et al. 2000, Suzuki et al. 2002). It seems that the expression pattern of the collagen XVIII isoforms change during development (Lin et al. 2001), suggesting that these molecules play important roles during development.

In 2000, we demonstrated that a mutation in the COL18A1 gene causes an autosomal recessive disorder, Knobloch syndrome, showing for the first time the functional importance of the collagen XVIII molecule in humans (Sertié et al. 2000). We will focus this review on the distribution of pathogenic and polymorphic mutations along the COL18A1 gene, their corresponding phenotypes and the possible functional roles of collagen XVIII based on the human and mice knockout phenotype. 


\section{PATHOGENIC MUTATIONS AND KNOBLOCH SYNDROME (KS)}

\section{PHENOTYPE}

Knobloch syndrome (KS; MIM 267750) is an autosomal recessive condition defined by the occurrence of high myopia, usually evidenced up to the first year of life, vitreoretinal degeneration with retinal detachment, macular abnormalities and occipital encephalocele. Clinical variability is present but, to date, all patients have severe ocular abnormalities that usually lead to bilateral blindness. The occipital encephalocele is also a major clinical feature that has been described in 23 of 25 reported cases; its size varies among affected patients and sometimes it is noticed only through CT scan (reviewed in Suzuki et al. 2002). Altered retinal pigmentation is a prominent finding and more recently it was described a case of persistent fetal vasculature in the eye of a patient with KS (Seaver et al. 1993, Passos-Bueno et al. 1994, Kliemann et al. 2003, Duh et al. 2004).

Heterotopic nodules in the lateral ventricules and neuronal migration abnormalities in three KS patients have recently been noticed (Kliemann et al. 2003, Fernando Kok, personal communication). In two of these patients epilepsy was also present, suggesting that these clinical complication might be more common in KS patients than in the general population. In one patient, sagital craniosynostosis was also present; confirmation of this association in additional cases will expand the spectrum of clinical variability in $\mathrm{KS}$.

Other minor clinical abnormalities, such as lens subluxation, cataracts, flat nasal bridge, midface hypoplasia, bilateral epicanthic folds, hypoplasia of the right lung with anomalous pulmonary return, cardiac dextroversion, generalized hyperextensibility of the joints, unusual palmar crease and unilateral duplicated renal collecting system, have been observed in a few cases (reviewed in Suzuki et al. 2002). The spectrum of clinical variability of KS is still not defined since most of each of the above mentioned clinical alterations were reported only once in single families and before the identification of the gene.

\section{IDENTIFICATION OF MUTATIONS IN THE COL18AI AS CAUSATIVE OF KS}

Based on the study of a single large inbred Brazilian family with 12 individuals affected with KS, we assigned the disease gene to 21q22.3 and demonstrated that a homozygous mutation at the AG consensus acceptor splice site of COL18A1 intron 1 (IVS1-2A $>$ T) causes Knobloch syndrome (Sertié et al. 2000). This mutation predicts the skipping of exon 2 and creation of a stop codon in exon 4 and, therefore, the truncation of only the a1(XVIII) collagen NC11-303 (Sertié et al. 2000). Patients with this mutation present endostatin plasma levels within the normal range (Suzuki et al. 2002). This is expected as the isoform $\mathrm{NC1}-493$, which produces most of the circulating endostatin, should not be altered by the presence of the IVS1-2A $>$ T mutation (Sertié et al. 2000, Suzuki et al. 2002).

Pathogenic mutations in the COL18A1 gene were found in 6 out of 9 other unrelated families with KS (3 Brazilian, 3 north-American and $3 \mathrm{Eu}-$ ropean), thus confirming that mutations in this gene causes KS. A total of 7 different pathogenic changes (Table I) were identified: three patients were compound heterozygotes and two homozygotes (O.T. Suzuki et al., unpublished data). Endostatin plasma levels, measured in 2 patients with null mutations, showed levels in the lower range, suggesting that these alterations lead to absence of the protein (Suzuki et al. 2002).

We did not identify mutations in three unrelated probands with the major typical clinical signs of the syndrome but, endostatin plasma levels, measured in two of them, showed values in the lower range (Suzuki et al. 2002, Kliemann et al. 2003). These data, therefore, suggest that the KS phenotype can be caused by an unusual mutational mechanism in COL18A1 or to non-allelic genetic heterogeneity, as also suggested by others (Menzel et al. 2004).

We also did not find pathogenic mutations in 
TABLE I

Pathogenic mutations found in KS patients.

Nucleotide numbers are based on the reference sequence AF018081.

\begin{tabular}{c|l}
\hline Family & Pathogenic mutations detected \\
\hline KS1 & c.12-2A $>\mathrm{T}^{*}$ (homozygous) \\
\hline $\mathrm{KS} 3$ & c.2969-2978delCAGGGCCCCC (maternal); c.3514-3515delCT (paternal) \\
\hline $\mathrm{KS} 4$ & c.1238-1239insA (maternal); c.3514-3515delCT (paternal) \\
\hline KS5 & c.3514-3515delCT (maternal); c.2105delC (paternal) \\
\hline KS8 & c.12-2A $>$ T (homozygous) \\
\hline KS9 & c.3277C $>$ T (homozygous) \\
\hline KS10 & c.2416C $>$ T (homozygous) \\
\hline
\end{tabular}

*mutation position based on the mRNA sequence AF018082.

KS patient who has high myopia associated with several other clinical features that were not typical of the syndrome: a scalp defect in the frontal region, developmental delay, telecanthus, hypertelorism, and high arched palate (Sniderman et al. 2000, Suzuki et al. 2002). This patient presented endostatin normal plasma levels. This finding suggests that this patient's phenotype is probably caused by mutations at another locus, and that mutations in COL18A1 cause very specific ocular and neuronal cell migration abnormalities. Therefore, the minimum clinical features that define the diagnosis of $\mathrm{KS}$ are high myopia and occipital encephalocele.

\section{GENOTYPE-PHENOTYPE CORRELATION IN KS}

All pathogenic mutations in the COL18A1 gene to date probably lead to mRNA decay or to a truncated protein thus the disease might be caused by deficiency of a functional protein. So, these mutations represent human knockout models for the COL18A1 gene: homozygotes for the IVS1-2T $>$ A represent a knockout of only the short isoform, while the other mutations represent knockout of all collagen XVIII isoforms and endostatin.

Patients with deficiency of only the short isoform present the main clinical features of the syndrome, suggesting that the lack of this isoform is enough to cause the phenotype. It also seems that lack of only the short isoform is associated with a less severe ocular prognosis. These observations imply that collagen XVIII isoforms may play important functional roles in the human eye. The ocular alterations observed in KS patients are complex and, for obvious reasons, it is difficult to obtain a detailed histology and electron microscopic characterization of a KS patient's eye. Thus, the histopathological and the molecular changes resulting from null COL18A1 alleles in humans remain unknown and the study of mice models will be of great importance to elucidate them. Indeed, there has been a growing number of data suggesting that the Knockout mice of coll8al(coll8al-/-) constitute a promising model to study KS. These mice are viable and fertile, do not present occipital encephalocele but show abnormal visual function due to several ocular alterations which worsen with increasing age (Fukai et al. 2002, Marneros and Olsen 2003, Marneros et al. 2004). Developmental defects in hyaloid vessel regression affecting postnatal levels of VEGF expression in the neural retina were observed in these mice (Fukai et al. 2002). Interestingly, Duh et al. (2004) described persistence of fetal vasculature in a patient with clinical features of Knobloch syndrome associated with no detectable plasma levels of endostatin. The iris basement mem- 
brane of the coll8al-/- mice was also shown to be altered (Marneros and Olsen 2003, Marneros et al. 2004), further confirming that iris modifications in some KS patients are due to the deficiency of collagen XVIII (Passos-Bueno et al. 1994, Duh et al. 2004). Another important finding in the mice coll8al-/- is the age-dependent accumulation of electron-dense deposits between the retinal pigment epithelium (RPE) and Bruch's membrane. These deposits contain excess basement membrane material and they were associated with an abnormal vitamin A metabolism in the retinal pigment epithelium with reduced rhodpsin levels (Marneros et al. 2004). These findings further confirm that endostatin/col18a1 plays a significant role in blood vessels remodeling and morphogenesis in the eye.

Variability of the size of the occipital alteration is commonly observed both in intra and interfamilial cases, but it does not have an obvious correlation with the site of the mutation in COL18A1 gene.

Pathogenic mutations leading to deficiency of all collagen XVIII isoforms were found in two out of $3 \mathrm{KS}$ patients who, besides minimum KS clinical features, also had abnormal neuronal cell migration and recurrent epilepsy. None of the 12 patients, all in middle age, with lack of only the short form of collagen XVIII has presented epilepsy; thus, we could speculate that the median and/or long collagen XVIII isoforms, in opposition to the short form, play an important role in neuronal cell migration. Alterations in neuronal cell migration have also been observed in col18a1 knockout animal models (Ackley et al. 2001). The current data, therefore, strongly support an important functional role of collagen XVIII in neuronal development. It is possible that the occipital encephalocele actually represents abnormal cell migration instead of a defect in bone or suture development at the occipital region.

Col18a1-/- mice, depending on the genetic background, develop a significant enlargement of the skull associated with severe hydrocephalus. This clinical alteration presents incomplete penetrance and wide expressivity, with some mice presenting just enlargement of the ventricles visible only through MRI (Utriainen et al. 2004). This phenotype was not noticed in KS patients, maybe due to the small number of cases studied to date.

One of the patients (homozygous for the mutation c.2416 C > T; numbered according to the mRNA sequence AF018081, deposited in GenBank) has a duplicated kidney (unpublished data). Lin et al. (2001) have shown that collagen XVIII expression is involved in kidney and lung morphogenesis, through still unknown mechanisms. Although no major kidney defect was observed among the mutant mice, they showed broadened kidney tubular basal membrane, altered mesangial matrix of the glomerulus and elevated serum creatinine levels (Utriainen et al. 2004). These findings further support the importance of collagen XVIII in kidney development and function. Therefore, KS patients should be carefully examined for functional and morphological kidney defects.

None of the patients with mutations in the COL18A1 gene have any major liver defect, which is surprising because one of the isoforms (NC11-493) is highly expressed in this organ.

\section{POLYMORPHIC CHANGES}

We identified twenty polymorphic variants in the COL18A1 gene (Iughetti et al. 2001, NCBI dbSNP database); of these, only two represent missense changes (I841V and D1437N). D1437N (previously referred as D104N) change is located in the $\mathrm{COOH}-$ terminal globular domain NC1 of collagen XVIII, the encoding region of endostatin. The aspartic acid at position 1437 (or amino acid residue 104 of endostatin) is conserved in human and mouse endostatin/collagen XVIII, as well as, in the endostatinlike molecule produced from the $\mathrm{NC1}$ domain of collagen XV (Iughetti et al. 2001). The structural modeling analysis of the human mutated $1437 \mathrm{~N}$ endostatin suggests that this amino acid residue is located at the surface of the molecule and does not change endostatin stability but can mod- 
ify the charged distribution surrounding the mutated aminoacid. (Iughetti et al. 2001).

It has been postulated that endostatin/collagen XVIII play important roles in tumor growth due to its anti-angiogenic activity. Indeed, we have observed that Down syndrome (DS) patients, who have a decreased incidence of solid tumors, showed higher serum levels of endostatin (Zorick et al. 2001). Still others have shown that patients with a better prognosis of hepatocelular carcinoma presented higher collagen XVIII expression in tumor cells (Musso et al. 2001) and lower production of the molecule by the surrounding stroma (Hu et al. 2005). Therefore, endostatin and collagen XVIII are good candidate proteins to be studied in the susceptibility of tumor growth. In this regard, we have hypothesized that the SNP D1437N (or D104N/endostatin) could represent an at-risk susceptibility allele for progression or aggressiveness of solid tumors. In a casecontrol study including 181 prostate cancer cases and 198 non-cancer individuals, we observed that the heterozygous N104 individuals have a 2.5 times increased chance of developing prostate cancer as compared with homozygous D104 subjects (Iughetti et al. 2001). However, this association was not confirmed by us in another sample (data not published) as well as by others including different solid tumors (Ortega et al. 2003, Liu et al. 2003, Nascimento et al. 2004, Macpherson et al. 2004). It is possible that the variation of the genotypic frequencies observed in our original report just represent racial stratification. Further studies will be necessary to understand the role of collagen XVIII/endostatin and predisposition to solid tumors.

\section{CONCLUSIONS}

Collagen XVIII, encoded by the COL18Al gene at $21 \mathrm{q} 22.3$, is a very interesting molecule, which produces at least two proteolytic fragments: one derived from its $\mathrm{C}$-terminal, endostatin and the other from its N-terminal, containing the frizzled motif. There are at least 3 distinct isoforms, which only differ at their N-terminal region; each of them present a specific tissue and development pattern of expression and possibly perform distinct functions.

Null alleles in the collagen XVIII lead to Knobloch Syndrome (KS), a rare autosomal recessive disorder mainly characterized by high myopia, vitreoretinal degeneration, macular alteration and occipital encephalocele. Iris and retinal pigment epithelium alteration seem also to be important features of the syndrome. The complete spectrum of the disease is still not established, but high myopia up to the first year of life and occipital encephalocele are the two minimal clinical criteria to classify a patient as KS. Collagen XVIII is a critical component of the basement membrane of the iris, vitreo and retina and its presence is fundamental for normal eye development during embryogenesis; this protein also seems to play important functional roles in neuronal cell migration and as a component of basement membrane of kidney. Polymorphisms in collagen XVIII are common, but their relationship to susceptibility of solid tumors are still controversial.

\section{ACKNOWLEDGMENTS}

The authors would like to thank the patients and their family for your enthusiasm and collaboration in the research. Authors are supported by Fundação de Amparo à Pesquisa do Estado de São Paulo (FAPESP), Centro de Pesquisa, Inovação e Difusão (CEPID), Conselho Nacional de Desenvolvimento Científico e Tecnológico (CNPq).

\section{RESUMO}

Colágeno XVIII, uma proteoglicana, é um componente das membranas basais (MBs). Existem três isoformas distintas que diferem apenas na região $\mathrm{N}$-terminal, mas que apresentam um padrão específico de expressão nos diferentes tecidos e durante o desenvolvimento. A clivagem da região C-terminal produz endostatina, um inibidor de angiogênese. Na sua região N-terminal, há um motivo "frizzled", o qual parece estar envolvido com a sinalização de Wnt. Mutações no gene COL18A1 causam a síndrome de Knobloch (SK), uma condição de herança autossômica recessiva caracterizada por degeneração vítreo 
- retiniana, degeneração de mácula e encefalocele occipital. Esta revisão discute o efeito tanto de alelos raros como polimórficos no fenótipo, mostrando que deficiência de uma das isoformas de colágeno XVIII é suficiente para causar SK e que alelos nulos causando deficiência de todas as isoformas de colágeno XVIII estão associadas a alterações oculares mais graves. Esta revisão, além de ilustrar a importância funcional do colágeno XVIII no desenvolvimento do olho e na manutenção de sua estrutura, também mostra que esta proteína tem um papel funcional importante em outros tecidos e órgão, como no sistema nervoso central e rim.

Palavras-chave: COL18A1, colágeno XVIII, síndrome de Knobloch, desenvolvimento ocular, migração de célula neuronal, craniossinostoses, polimorfismos, D1437N.

\section{REFERENCES}

Abdollahi A, Hahnfeldt P, Maercker C, Grone HJ, Debus J, Ansorge W, Folkman J, HLATKY L AND HUBER PE. 2004. Endostatin's antiangiogenic signalling network. Mol Cell 13: 649-663.

Ackley BD, Crew JR, ElamaA H, Pihlajaniemi T, Kuo CJ AND Kramer JM. 2001. The NC1/ endostatin domain of Caenorhabditis elegans type XVIII collagen affects cell migration and axon guidance. J Cell Biol 152: 1219-1232.

ARicescu AR, MCKinnell IW, Halfter W AND STOKER AW. 2002. Heparan sulfate proteoglycans are ligands for receptor protein tyrosine phosphatase sigma. Mol Cell Biol 22: 1881-1892.

Dhanabal M, RAMChANDRAN R, WATERMAN MJ, Lu $\mathrm{H}$, Knebelmann B, Segal M And SUKHATME VP. 1999. Endostatin induces endothelial cell apoptosis. J Biol Chem 274: 11721-11726.

DHAR DK, ONO T, YAMANOI A, SODA Y, YAMAGUChi E, Rahman MA, KoHno H and NaGASUE N. 2002. Serum endostatin predicts tumor vascularity in hepatocellular carcinoma. Cancer 95: 2188-2195.

DiXelius J, LARsson H, SASAKi T, HolmQvist K, Lu L, Engstrom A, Timpl R, Welsh M AND Claesson-Welsh L. 2000. Endostatin-induced tyrosine kinase signalling through the Shb adaptor protein regulates endothelial cell apoptosis. Blood 95: 3403-3411.
Duh EJ, Yao YG, Dagli M and Goldberg MF. 2004. Persistence of fetal vasculature in a patient with Knobloch syndrome: potential role for endostatin in fetal vascular remodeling of the eye. Ophthalmology 111: 1885-1888.

ElamaA H, Snellman A, Rehn M, AutioHARMAinen H AND PihlajaniEmi T. 2003. Characterization of the human type XVIII collagen gene and proteolytic processing and tissue location of the variant containing a frizzled motif. Matrix Biol 22: $427-442$.

Felbor U, Dreier L, Bryant RA, Ploegh HL, Olsen BR AND Mothes W. 2000. Secreted cathepsin L generates endostatin from collagen XVIII. EMBO J 19: 1187-1194.

FUKAI N ET AL. 2002. Lack of collagen XVIII/ endostatin results in eye abnormalities. EMBO J 21: 1535-1544.

Hu TH, HuANG CC, Wu CL, LIN PR, LIU SY, LiN JW, Chuang JH AND TAI MH. 2005. Increased endostatin/collagen XVIII expression correlates with elevated VEGF level and poor prognosis in hepatocellular carcinoma. Mod Pathol 18: 663-672.

IUGhetti P ET AL. 2001. A polymorphism in endostatin, an angiogenesis inhibitor, predisposes for the development of prostatic adenocarcinoma. Cancer Res 61: 7375-7378.

John H, RADTKE K, STANDKER L AND ForssmanN WG. 2005. Identification and characterization of novel endogenous proteolytic forms of the human angiogenesis inhibitors restin and endostatin. Biochim Biophys Acta 1747: 161-170.

KARIHAlOO A ET AL. 2001. Endostatin regulates branching morphogenesis of renal epithelial cells and ureteric bud. Proc Natl Acad Sci USA 98: 12509 12514.

KARUMANCHI AS ET AL. 2001. Cell surface glypicans are low-affinity endostatin receptors. Mol Cell 7: 811-822.

Kliemann SE, Waetge RT, Suzuki OT, PassosBueno MR And Rosemberg S. 2003. Evidence of neuronal migration disorders in Knobloch syndrome: clinical and molecular analysis of two novel families. Am J Med Genet A 119: 15-19.

Lin Y, Zhang S, REHN M, ITARANTA P, TUUKKA- 
nen J, Heljasvaara R, Peltoketo H, PihlaJANIEMI T AND VAINIO S. 2001. Induced repatterning of type XVIII collagen expression in ureter bud from kidney to lung type: association with sonic hedgehog and ectopic surfactant protein C. Development 128: 1573-1585.

Liu TC, Peng CT, Lin SF, Chang CS, Chen TP AND ChAng JG. 2003. Association of endostatin D104N with leukemia. Kaohsiung J Med Sci 19: $1-5$.

Macpherson GR, Singh AS, Bennett CL, VenZON DJ, LIEWEHR DJ, FRANKS ME, DAHUT WL, Kantoff PW, Price DK and Figg WD. 2004. Genotyping and Functional Analysis of the D104N Variant of Human Endostatin. Cancer Biol Ther 3: 1298-1303.

Marneros AG and Olsen BR. 2003. Age-dependent iris abnormalities in collagen XVIII/endostatin deficient mice with similarities to human pigment dispersion syndrome. Invest Ophthalmol Vis Sci 44: 2367-2372.

MARneros AG ET AL. 2004. Collagen XVIII/ endostatin is essential for vision and retinal pigment epithelial function. EMBO J 23: 89-99.

MENZEL O ET AL. 2004. Knobloch syndrome: novel mutations in COL18A1, evidence for genetic heterogeneity, and a functionally impaired polymorphism in endostatin. Hum Mutat 23: 77-84.

Musso O, Rehn M, Theret N, Turlin B, Bioulac-Sage P, Lotrian D, CAMpion JP, Pihlajaniemi T and Clement B. 2001. Tumor progression is associated with a significant decrease in the expression of the endostatin precursor collagen XVIII in human hepatocellular carcinomas. Cancer Res 61: 45-49.

NAscimento H, Rodrigues Coy CS, NAVARro Goes JR, Ferreira Costa F And PAssos Lima CS. 2004. A polymorphism in the angiogenesis inhibitor, endostatin, in sporadic colorectal adenocarcinoma. Int J Colorectal Dis 19: 499-501.

Oh SP, Warman ML, Seldin MF, Cheng SD, KnOLL JH, Timmons S AND Olsen BR. 1994. Cloning of cDNA and genomic DNA encoding human type XVIII collagen and localization of the alpha 1(XVIII) collagen gene to mouse chromosome 10 and human chromosome 21. Genomics 19: 494-499.
Ortega MM, Nascimento H, Costa FF, Teori MT AND LIMA CS. 2003. A polymorphism in the angiogenesis inhibitor, endostatin, in multiple myeloma. Leuk Res 27: 93-94.

Passos-Bueno Mr, Marie SK, Monteiro M, Neustein I, Whittle MR, Vainzof M AND ZATZ M. 1994. Knobloch syndrome in a large Brazilian consanguineous family: confirmation of autosomal recessive inheritance. Am J Med Genet 52: $170-173$.

Rehn M And Pihlajaniemi T. 1994. Alpha 1(XVIII), a collagen chain with frequent interruptions in the collagenous sequence, a distinct tissue distribution, and homology with type XV collagen. Proc Natl Acad Sci USA 91: 4234-4238.

RehN M, VeikKola T, KuKK-VAldre E, NAKAMURA H, ILmONen M, LOMBARdo C, PihlaJANiEMI T, ALiTALO K AND VUORI K. 2001. Interaction of endostatin with integrins implicated in angiogenesis. Proc Natl Acad Sci USA 98: 10241029.

SaArela J, Ylikarppa R, Rehn M, Purmonen S And Pihlajaniemi T. 1998. Complete primary structure of two variant forms of human type XVIII collagen and tissue-specific differences in the expression of the corresponding transcripts. Matrix Biol 16: 319-328.

SASAKi T, FuKAi N, MANn K, GOHRING W, Olsen BR AND TIMPL R. 1998. Structure, function and tissue forms of the C-terminal globular domain of collagen XVIII containing the angiogenesis inhibitor endostatin. EMBO J 17: 4249-4256.

Schmidt A, Wenzel D, Ferring I, Kazemi S, SASAKi T, Hescheler J, Timpl R, AdDicks K, FleischmanN BK AND Bloch W. 2004. Influence of endostatin on embryonic vasculo- and angiogenesis. Dev Dyn 230: 468-480.

SeAVER LH, Joffe L, SPARK RP, SMith BL AND HOYME HE. 1993. Congenital scalp defects and vitreoretinal degeneration: redefining the Knobloch syndrome. Am J Med Genet 46: 203-208.

Sertié AL, Sossi V, Camargo AA, Zatz M, Brahe C And Passos-Bueno MR. 2000. Collagen XVIII, containing an endogenous inhibitor of angiogenesis and tumor growth, plays a critical role in the maintenance of retinal structure and in neural 
tube closure (Knobloch syndrome). Hum Mol Genet 9: 2051-2058.

SNiderman LC, KOENEKOOP RK, O'Gorman AM, Usher RH, Sufrategui MR, Moroz B, WATTERS GV AND DER Kaloustian VM. 2000. Knobloch syndrome involving midline scalp defect of the frontal region. Am J Med Genet 90: 146-149.

Strik HM, Schluesener HJ, Seid K, MeyerMANN R AND DEININGER MH. 2001. Localization of endostatin in rat and human gliomas. Cancer 91: 1013-1019.

SUZUKI OT ET AL. 2002. Molecular analysis of collagen XVIII reveals novel mutations, presence of a third isoform, and possible genetic heterogeneity in Knobloch syndrome. Am J Hum Genet 71: 13201329.

Utriainen A, Sormunen R, Kettunen M, Carvalhaes LS, Sajanti E, Eklund L, KAUpPinen R, Kitten GT AND Pihlajaniemi T. 2004. Structurally altered basement membranes and hydrocephalus in a type XVIII collagen deficient mouse line. Hum Mol Genet 13: 2089-2099.

Wen W, Moses MA, Wiederschain D, Arbiser JL AND FOLKMAN J. 1999. The generation of endostatin is mediated by elastase. Cancer Res 59: 6052-6056.
Wickstrom SA, Alitalo K and Keski-Oja J. 2002. Endostatin associates with integrin alpha5beta1 and caveolin-1, and activates Src via a tyrosyl phosphatase-dependent pathway in human endothelial cells. Cancer Res 62: 5580-5589.

Wickstrom SA, Alitalo K And Keski-Oja J. 2004. An endostatin-derived peptide interacts with integrins and regulates actin cytoskeleton and migration of endothelial cells. J Biol Chem 279: 20178-20185.

WodArz A AND Nusse R. 1998. Mechanisms of Wnt signalling in development. Annu Rev Cell Dev Biol 14: 59-88.

XU YK AND Nusse R. 1998. The Frizzled CRD domain is conserved in diverse proteins including several receptor tyrosine kinases. Curr Biol 8: R405-406.

ZORICK TS, MUSTACCHI Z, BANDO SY, ZATZ M, Moreira-Filho CA, Olsen B ANd PassosBUENO MR. 2001. High serum endostatin levels in Down syndrome: implications for improved treatment and prevention of solid tumours. Eur J Hum Genet 9: 811-814. 